\title{
MENATA ULANG LEMBAGA PENDIDIKAN ISLAM SEBAGAI UPAYA MENINGKATKAN MUTU
}

\author{
Muhammad Fadhli \\ Penulis adalah Dosen Manajemen Pendidikan Ilsam Pada Fakultas Tarbiyah dan \\ Ilmu Keguruan IAIN Lhokseumawe \\ Email: fadhlikhan88@gmail.com
}

\begin{abstract}
Islamic Education as a form of teaching and learning based on the principles and values of Islam. Education in Islam is a means towards the improvement of morals. In other words, education in Islam is a function to achieve the sublime morals, while educational institutions are aspects of material to perform these functions. Rearrangement or school improvement is a systematic effort, sustained intended to change the learning process and other related internal conditions in schools, with the goal of achieving educational goals more effectively. Structuring educational institutions as an approach to educational change that has two purposes: 1) to improve student achievement and, 2) to strengthen the school's capacity for managing change. School improvement approach everything should have the ultimate goal kepasa efforts to improve student achievement. Efforts to improve the school should not be based on the state of the schools that have a shortage / low-quality. Due to the increasingly dynamic changing times then the school must continue to improve its quality. Because the schools that already have a good quality can continue to get better again.
\end{abstract}

Keywords: Penaaan Repeat. Institutions of Islam, Quality Improvement

\section{PENDAHULUAN}

Perkembangan pendidikan islam di Indonesia sebenarnya sudah menunjukkan ke arah yang lebih baik. Lahirnya lembaga pendidikan islam seperti, madrasah insan cendikia, Sekolah Dasar Islam Terpadu, pondok pesantren yang berbasis IT dan sebagainya. Hal ini tentunya memberikan harapan akan lahirnya generasi Islami yang tidak hanya memilki kemampuan dalam bidang ke-Islaman tetapi juga dalam bidang umum lainnya.

Lahirnya generasi islam yang memilki kemampuan komprehensif (memilki pemahaman yang luas dan lengkap serta mempunyai dan memperlihatkan wawasan yang luas) merupakan tujuan pendidikan Islam. Sanaky menyebut istilah tujuan pendidikan Islam dengan visi dan misi pendidikan Islam. Menurutnya sebenarnya pendidikan Islam telah memiki visi dan misi yang ideal, yaitu "Rohmatan Lil 'Alamin". Selain itu, sebenarnya konsep dasar filosofis pendidikan Islam lebih mendalam dan menyangkut persoalan hidup multi dimensional, yaitu pendidikan yang 
tidak terpisahkan dari tugas kekhalifahan manusia, atau lebih khusus lagi sebagai penyiapan kader-kader khalifah dalam rangka membangun kehidupan dunia yang makmur, dinamis, harmonis dan lestari sebagaimana diisyaratkan oleh Allah dalam Alquran. Pendidikan Islam adalah pendidikan yang ideal, sebab visi dan misinya adalah "Rohmatan Lil 'Alamin", yaitu untuk membangun kehidupan dunia yang yang makmur, demokratis, adil, damai, taat hukum, dinamis, dan harmonis ${ }^{1}$.

Dalam alquran surat Adz-Dzariyat ayat 56 ditegaskan:

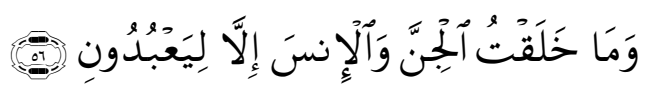

Artinya: "Dan Aku tidak menciptakan jin dan manusia melainkan supaya mereka menyembah-Ku".(Q.S.Adz-Dzariyat:56).

Sesuai dengan ayat diatas maka tujuan pendidikan Islam tidak terlepas dari tujuan hidup manusia dalam Islam, yaitu untuk menciptakan pribadi-pribadi hamba Allah yang selalu bertakwa kepadaNya, dan dapat mencapai kehidupan yang berbahagia di dunia dan akhirat. Lebih lanjut dalam upaya pencapaian tujua pendidikan Islam, maka lembaga-lembaga pendidikan Islam harus mampu menjadikan generasi islam terampil mengabdi kepada Allah sesuai dengan perkembangan zaman.

Menurut Tan menjelaskan Islamic education as any form of teaching and learning that is based on the principles and values of Islam. Pendapat ini menjelaskan pendidikan Islam sebagai bentuk pengajaran dan pembelajaran yang didasarkan pada prinsip-prinsip dan nilai-nilai Islam ${ }^{2}$. Kemudian Hidayat pendidikan dalam Islam merupakan sarana untuk menuju ke arah penyempurnaan akhlak. Dengan kata lain, pendidikan dalam Islam adalah fungsi untuk mencapai keluhuran akhlak, sedangkan lembaga pendidikan adalah aspek material untuk menjalankan fungsi tersebut. Pendidikan adalah substansinya, sedangkan lembaga pendidikan adalah institusi atau pranatanya yang telah terbentuk secara ajeg dan mapan di tengah-tengah masyarakat ${ }^{3}$

Pendidikan Islam yang berkualitas merupakan cita-cita bersama bangsa Indonesia. Untuk itu dalam upaya pencapaiannya tentunya diperlukan berbagai upaya-

\footnotetext{
${ }^{1}$ Sanaky, H. (2003). Paradigma Pendidikan Islam; Membangun Masyarakat Indonesia, Yogyakarta: Safiria Insania Press dan MSI. Hal 142

${ }^{2}$ Tan, C. (2011). Islamic Education and Indoctrination The Case in Indonesia. New York: Routledge, hal 4

${ }^{3}$ Hidayat, R. (2016). Ilmu Pendidikan Islam "Menuntun Arah Pendidikan Islam Indonesia. Medan: LPPPI
} 
upaya nyata. Upaya yang dapat dilakukan adalah terus berupaya meningkatkan lembaga-lembaga pendidikan Islam yang berkualitas.

Namun saat ini tercapaianya kualitas lembaga-lembaga pendidikan islam hanya merupakan sebahagian kecil dari seluruh lembaga pendidikan islam yang ada. Tan Dari 50.000 sekolah Islam di Indonesia, 16.015 di antaranya pesantren (pesantren), 37.000 di antaranya adalah madrasah (sekolah hari Islam) dan minoritas kecil adalah Sekolah Islams. Pendaftaran di sekolah-sekolah Islam telah meningkat sejak akhir 1980-an. Saat ini sekitar 5,7 juta atau 13 persen dari 44 juta siswa yang terdaftar dalam sistem pendidikan formal terdaftar di madrasah ${ }^{4}$.

Pesatnya perkembangan pendidikan Islam harus diikuti dengan perkembangan kualitas lembaga pendidikan Islam tersebut. Sekolah-sekolah Islam di Indonesia dapat dibagi menjadi tiga jenis utama: pesantren, madrasah, dan sekolah Islam.

\section{PEMBAHASAN}

\section{Jenis Lembaga Pendidikan Islam}

\section{A. Pesantren}

Pondok pesantren pada dasarnya tidak dapat diberikan batasan yang nyata karena memliki fleksibilitas defenisi. Hal ini menjadikan pondok pesantren belum dapat diberikan pengertian yang tegas. Jadi pondok pesantren belum ada pengertian yang lebih konkrit karena masih meliputi beberapa unsur untuk dapat mengartikan pondok pesantren secara komprehensif. Dengan demikian, sesuai dengan arus dinamika zaman, definisi serta persepsi terhadap pesantren menjadi berubah pula. Pada tahap awal pesantren diberi makna dan pengertian sebagai lembaga pendidikan tradisional tetapi saat ini jika pesantren dimkanai sebagai lembaga pendidikan tradisional maka tidak lagi sepenuhnya benar.

Namun para ahi pendidikan Islam telah berupaya memberikan defenisi tentang pondok pesantren. Menurut Fuad dan Suwito pesantren berasal dari kata santri yang diberi awalan "pe" dan akhiran "an" yang dikarenakan pengucapan kata itu kemudian berubah menjadi terbaca "en" (pesantren), yaitu sebutan untuk bangunan fisik atau asrama di mana para santri bertempat. Tempat itu dalam bahasa Jawa dikatakan pondok atau pemondokan. Adapun kata santri sendiri berasal dari kata cantrik, yang

\footnotetext{
${ }^{4}$ Tan, C. (2011). Islamic Education and Indoctrination The Case in Indonesia. New York: Routledge, hal 92
} 
berarti murid dari seorang resi yang juga biasanya menetap dalam satu tempat yang dinamakan dengan padepokan. Pesantren mempunyai persamaan dengan padepokan dalam beberapa hal, yakni adanya murid (cantrik dan santri), adanya guru (kiai dan resi), adanya bangunan (pesantren dan padepokan), dan terakhir adanya kegiatan belajar mengajar ${ }^{5}$.

Sedang Berg dalam Yusmadi berpendapat bahwa istilah pesantren berasal dari kata shastri yang dalam bahasa India berarti orang yang tahu buku-buku suci agama Hindu, atau seorang sarjana ahli kitab-kitab suci agama Hindu. Kata shastri berasal dari kata shastra yang berarti buku-buku suci, buku-buku suci agama atau buku-buku tentang ilmu pengetahuan ${ }^{6}$.

Pesantren harusnya bersifat mandiri, dan tidak tergantung kepada pemerintah atau kekuasaan yang ada. Pesantern bisa memegang teguh kemurniannya sebagai lembaga pendidikan Islam jika kemandiriannya tetap terjaga. Karena itu pesantren tidak mudah disusupi oleh ajaran-ajaran yang tidak sesuai dengan ajaran Islam. Dalam sejarahnya, pesantren selalu didirikan oleh ulama yang sudah menyandang predikat kyai. Bahkan ada pendapat di berbagai daerah, bahwa seorang ulama pantas menyandang gelar kyai, apabila ia sudah mendirikan atau memiliki pesantren.

\section{B. Madrasah}

Jenis sekolah Islam yang kedua adalah madrasah. Meskipun sebuah madrasah dikenal sebagai sekolah harian Islam di Indonesia. Madrasah diperkenalkan oleh presiden Indonesia pertama, Soekarno madrasah menggabungkan pendidikan agama tradisional dengan komponen umum yang luas ${ }^{7}$. Mayoritas madrasah adalah milik pribadi/ yayasan, dengan madrasah negeri yang mencakup antara 6,4 persen dan 13 persen dari tingkat MI sampai MA. Selain sekolah non-asrama, madrasah dibedakan dari pesantren dalam tujuannya. Dengan pendekatan yang lebih modern untuk manajemen madrasaha, kurikulum, dan pedagogi. Tidak seperti pesantren yang terutama bertujuan untuk membina para sarjana agama, madrasah dibentuk untuk menciptakan umat Islam yang siap untuk pekerjaan profesional diluar bidang

\footnotetext{
${ }^{5}$ Yusuf, C. dan Suwito, NS (2009). Model Pengembangan Ekonomi Pesantren. Purwokerto: STAIN Press. Hal 28

${ }^{6}$ Yasmadi. (2005). Modernisasi Pesantren. Jakarta: Ciputat Press. Hal 61

${ }^{7}$ Tan, C. (2011). Islamic Education and Indoctrination The Case in Indonesia. New York: Routledge, hal 94
} 
keagamaan. Madrasah tu menawarkan kepada siswa-siswa mereka berbagai macam seperti, ruang kelas modern dengan papan tulis, buku pelajaran, dan penilaian terstruktur. Semua madrasah saat ini mengadopsi kurikulum madrasah yang disetujui pemerintah yang terdiri penggabungan ilmu-ilmu agama dengann ilmu umum. Madrasah disetarakan dengan sekolah umum dalam Undang-Undang Pendidikan Nomor 2 tahun 1989 dan juga Undang-undang nomor 20 Tahun 2003 tentang sistem pendidikan nasional. Madrasah mengikuti kurikulum nasional sepenuhnya dan lulusan mereka dapat melanjutkan studi mereka di Perguruan Tinggi Keagamaan Islam (PTKI) dan Perguruan Tinggi Umum (PTU). Sementara sekolah umum hanya menawarkan dua jam pelajaran agama Islam per minggu, madrasah menawarkan lima mata pelajaran keagamaan yaitu: Bahasa Arab, Aqidah Akhlak, Fikih, Quran Hadis, Sejrah Islam.

\section{Sekolah Islam Terpadu}

Munculnya Sekolah-sekolah Islam Terpadu merupakan respon atas ketidakpuasan terhadap Sistem Pendidikan Nasional yang dianggap tidak mampu menjawab kebutuhan dan tantangan zaman, khususnya yang berhubungan dengan kemajuan ilmu pengetahuan dan teknologi. Sistem pendidikan nasional dianggap gagal membentuk moral para siswa dan melindungi mereka dari penggunaan obat-obat terlarang, pergaulan bebas, dan kenakalan. Kekhawatiran seperti ini terutama menyebabkan orang-orang kota yang secara langsung menyaksikan pengaruh negatif dari modernisasi dan globalisasi. Hal itu juga dipengaruhi oleh adanya kesadaran sebagian kalangan Muslim mengenai perlunya menggabungkan antara ilmu pengetahuan umum dengan pendekatan Islam $^{8}$. Sekolah Islam Terpadu pada hakekatnya adalah sekolah yang mengimplementasikan konsep pendidikan Islam berlandaskan AlQur'an dan As Sunnah. Konsep operasional SIT merupakan akumulasi dari proses pembudayaan, pewarisan dan pengembangan ajaran agama Islam, budaya dan peradaban Islam dari generasi ke generasi. Istilah "Terpadu" dalam SIT dimaksudkan sebagai penguat (taukid) dari Islam itu sendiri.

Pendidikan Islam terpadu, sesungguhnya merupakan salah satu bentuk respon umat Islam terhadap kehidupan moderen. Hal tersebut diwujudkan dengan upaya

\footnotetext{
${ }^{8}$ Kurnaengsih. (2015). Konsep Sekolah Islam Terpadu (Kajian Pengembangan Lembaga Pendidikan Islam di Indonesia). Jurnal Risaalah. 1 (1). 78-84
} 
memadukan antara konsep pendidikan Islam yang integral dengan metode dan sistem pendidikan modern.

Sekolah agama terpadu adalah sekolah yang memadukan antara pelajaran umum berdasarkan kurikulum nasional dengan pelajaran agama. Kebanyakan yang dimaksud dengan sekolah agama terpadu adalah sekolah Islam terpadu. Untuk di Surabaya, yang saya tahu pionirnya adalah sekolah Al Hikmah. Tapi sekarang sudah cukup banyak sekolah seperti ini di seluruh penjuru Surabaya dan Sidoarjo. Begitu banyak muatannya sekolah ini, maka jam pelajarannya menjadi lebih panjang. Bisa hampir seharian. Sehingga sekolah ini sering dinamakan sebagai 'full day school'. Karena melewati jam makan siang, maka siswa sekolah ini perlu makan siang. Biasanya sekolah menyediakan makan siangnya. Meski ada yang meminta siswanya membawa bekal dari rumah.

Jadi di sekolah Islam terpadu ini, para siswa selain belajar pelajaran umum seperti matematika, bahasa Indonesia, IPA, IPS dan lainnya juga belajar agama. Pelajaran yang terkait dengan agama ini di antaranya mengaji, hafalan doa, hafalan hadits, shalat jamaah wajib dan sunnah (seperti Dhuha), sejarah Islam, fiqih dan lainnya. Termasuk juga pembentukan akhlak, tingkah laku dan kebiasaan Islami.

\section{Konsep Penataan Ulang Lembaga Pendidikan Islam}

Setiap sekolah pasti dan harus memiliki manajemen sekolah yang diatur oleh sumberdaya sekolah. Namun yang menjadi tanda tanya apakah manajemen yang di implementasikan tersebut memilki efektivitas untuk mencapai tujuan pendidikan yang universal. Menurut Hillman and Stoll dalam Myers menjelaskan the ultimate aim of school improvement is to achieve a range of goals that will enhance learning, achievement and development amongst pupil. Pendapat ini menjelaskan bahwa tujuan utama dari peningkatan/ perbaikan sekolah adalah untuk mencapai berbagai sasaran yang bermuara pada meningkatnya proses dan hasil pembelajaran, pencapaian dan pengembangan prestasi siswa ${ }^{9}$.

Pendapat yang hampir sama diungkapkan oleh Hopkins dkk menjelaskan school improvement as an approach to educational change that has the twin purposes of enhancing pupil achievement and strengthening the school's capacity for managing

\footnotetext{
${ }^{9}$ Myers, K. (2005). School Improvement in Practice: Schools Make A Difference. London: Falmer Press, hal 12
} 
change $^{10}$. Pendapat ini mendefinisikan peningkatan sekolah sebagai pendekatan untuk perubahan pendidikan yang memiliki dua tujuan yaitu: 1) untuk meningkatkan prestasi siswa dan, 2) memperkuat kapasitas sekolah untuk mengelola perubahan. Pendekatan peningkatan sekolah semuanya harus memilki tujuan akhir kepasa upaya untuk meningkatkan prestasi siswa.

Poster menjelaskan kerangka kerja penataan ulang lembaga sekolah menuju penignkatan sekolah dalam tabel berikut ${ }^{11}$ :

Tabel 1 Kerangka Kerja Untuk Analisis Penataan Ulang Lembaga Pendidikan

\begin{tabular}{|l|l|}
\hline Roles (Peran) & $\begin{array}{l}\text { Kepemimpinan - pemerintah, Struktur manajemen, } \\
\text { spesifikasi pekerjaan, batasan manajemen }\end{array}$ \\
\hline Relationships (Hubungan) & $\begin{array}{l}\text { Hubungan staf, Pengembangan staf, Keterlibatan orang } \\
\text { tua, Persepsi masyarakat, tanggung jawab pemerintah }\end{array}$ \\
\hline Rules (Aturan) & $\begin{array}{l}\text { Kebijakan sekolah, kontrol keuangan, sistem } \\
\text { administrasi }\end{array}$ \\
\hline Results (Hasil) & $\begin{array}{l}\text { Ulasan rencana pengembangan sekolah, Pemantauan dan } \\
\text { evaluasi, prestasi siswa, kontrol kualitas }\end{array}$ \\
\hline
\end{tabular}

Kontribusi dari kepala sekolah, staf dan siswa serta dari semua pihak yang terlibat di sekolah adalah unsur yang sangat penting untuk upaya pencapaian keberhasilan peningkatan sekolah.

Upaya peningkatan sekolah tidak harus berdasarkan pada keadaan sekolah yang memilki kekurangan/ mutu yang rendah. Karena perubahan zaman yang semakin dinamis maka sekolah harus terus berupaya meningkatkan mutunya. Karena sekolahsekolah yang sudah memilki mutu yang baik dapat terus menjadi lebih baik lagi. Reynolds dkk dalam Myers memberikan rangkuman bermanfaat tentang bagaimana memprakarsai perubahan dan perbaikan sekolah selama tiga puluh tahun terakhir dalam Tabel 3 beikut $^{12}$ :

Tabel 3 Karakteristik Dua Paradigma Peningkatan Sekolah

\footnotetext{
${ }^{10}$ Hopkins, D., Stoll, L., Myers, K., Learmonth, J. And Durman, H. (1995). Schools Make A Difference: Practical Strategies For School Improvement, (Study Guide To Accompany The Channel 4 Series), Southampton, Resource Base Television Centre

${ }^{11}$ Myers, K. (2005). School Improvement in Practice: Schools Make A Difference. London: Falmer Press, hal $132-133$

12 Ibid, Myers, hal 14
} 


\begin{tabular}{|l|l|l|}
\hline Orientasi & Tahun 80an "Top Down" & Tahun 90an "Bottom Up" \\
\hline $\begin{array}{l}\text { Dasar Pengetahuan } \\
\text { (Knowledge Base) }\end{array}$ & Pengetahuan Elit & Pengetahuan Praktis \\
\hline Sasaran (Target) & $\begin{array}{l}\text { Berdasarkan organisasi atau } \\
\text { kurikulum }\end{array}$ & Berdasarkan proses \\
\hline Hasil (Outcome) & Berorientasi pada prestasi siswa & $\begin{array}{l}\text { Berorientasi pada proses } \\
\text { pendidikan }\end{array}$ \\
\hline Tujuan (Goals) & Hasil seperti pemberian (Bakat) & $\begin{array}{l}\text { Kemampuan pemecahan } \\
\text { masalah }\end{array}$ \\
\hline Fokus (Focus) & Sekolah & Guru \\
\hline $\begin{array}{l}\text { Metode Evaluasi } \\
\text { (Methodology } \\
\text { Evaluation) }\end{array}$ & Kuantitatif & Kualitatif \\
\hline Tempat (Site) & Di luar sekolah & Di Sekolah \\
\hline Fokus (Focus) & Sebahagian dari sekolah & Keseluruhan sekolah \\
\hline
\end{tabular}

Karakteristik yang tercantum dalam Tabel diatas gambaran dari pernyataan definitif. Namun table di atas mencoba menyampaikan pendekatan yang berbeda untuk perbaikan sekolah. Tahap awal di bidang ini dilakukan untuk perbaikan sekolah dan mengasumsikan bahwa basis pengetahuan yang akurat dan tidak terpecah serta terkonsentrasi pada hasil siswa yang terukur (biasanya nilai ujian). Pada tahun 1980-an banyak pekerjaan perbaikan sekolah bersifat kuantitatif, berkonsentrasi pada organisasi dan pencapaian kurikulum, sering berfokus pada sekolah dan individu daripada seluruh sekolah. Pada 1990-an tampaknya ada langkah yang realistis dan logis untuk berkonsentrasi pada karakteristik yang tercantum di atas yang sesuai dengan upaya daripada yang sesuai dengan paradigma tertentu.

Hargreaves dan rekan-rekannya dalam Myers mengusulkan agar sekolahsekolah harus memperhatikan empat jenis pencapaian/ prestasi siswa yang dituangkan dalam laporan Sekolah (buku rapor sekolah) yang diuraikan dalam tabel 1 berikut $^{13}$ :

Tabel 1 Aspek Prestasi Siswa

\begin{tabular}{|l|l|}
\hline Aspect 1 & Dealing with the capacity to remember and use facts \\
\hline Aspect 2 & Practical and spoken skills \\
\hline Aspect 3 & Personal and social skills \\
\hline Aspect 4 & Motivation and self-confidence \\
\hline
\end{tabular}

Tabel diatas menunjukkan bahwa prestasi ataun pencapaian yang menjadi proiritas dalam proses pembelajaran di sekolah tidak hanya pada aspek kemampuan

\footnotetext{
${ }^{13}$ Myers, K. (2005). School Improvement in Practice: Schools Make A Difference. London: Falmer Press, hal 13
} 
kognitif atau nilai-nilai akhir saja namun ada 4 aspek utama yang harus di capai yaiut: 1) memilki kapasitas untuk mengingat dan menggunakan fakta-fakta;, 2) memilki keterampilan baik secara praktis maupun lisan; memiliki keterampilan kepribadian dan sosial; serta 4) memilki motivasi dan kepercayaan diri yang tinggi.

Rutter et al. menjelaskannya dalam seluruh temuan penelitian terperinci yang mereka mereka lakukan tentang apa yang sebenarnya terjadi di kelas dan sekolah, bahwa faktor-faktor kualitatif tertentu menghasilkan peningkatan prestasi siswa. Kepala sekolah merupakan salah satu faktor internal yang penting yang harus melakukan hal berikut:

1) Menekankan pada proses belajar mengajar dan membentuk komunitas belajar di seluruh staf sekolah;

2) Adanya kesepakatan antara manajemen dan pimpinan yang berorientasi pada pencapaian tujuan;

3) Memiliki iklim belajar yang mendukung, yang mencakup hubungan yang kuat dengan orang tua; dan

4) Memilki harapan yang tinggi akan prestasi akademik dan pertumbuhan kompetensi sosial.

Kepala sekolah harus memilki kompetensi dan kecakapan yang cukup untuk dapat mewujudkan ke empat poin penting diatas. Kepala sekolah tentunya harus memilki visi yang jelas untuk dapat menjadikan sekolah menjadi lebih baik.

\section{Upaya Menata Ulang Lembaga Pendidikan Islam}

Dewasa ini terjadi ketimpangan yang sangat nyata antara sekolah satu dengan sekolah lainnya. Tidak perlu meninjau sampai kepelosok daerah, di kota-kota besarpun akan dengan mudah kita menemukan ketimpangan tersebut. Sekolah yang sudah baik mutunya akan terus mengalami peningkatan karena akan menemukan di dalamnya penguatan untuk praktik-praktik baik yang mereka terapkan, dan sekolah yang belum mencapai mutu yang baik tidak akan tahu bagaimana memperkenalkan dan menerapkan perubahan-perubahan secara kualitatif yang diperlukan.

Penataan ulang atau perbaikan sekolah merupakan upaya sistematis, berkelanjutan yang ditujukan untuk perubahan proses belajar mengajar dan kondisi internal terkait lainnya di sekolah, dengan tujuan mencapai tujuan pendidikan yang lebih efektif'. 
Pendapat ini memberikan penekanan bahwa untuk dapat mencapai perubahanperubahan sekolah yang bertujuan pada peningkatan mutu sekolah harus menjadikan sekolah sebgaia pusat dari perubahan perubahan tersebut. Kemudian menempat kondisi internal yang kurang sehat sebagai fokus utama dalam perubahan sekolah. Perumusan ulang tujuan pendidikan sebagai upaya pencapaian tujuan yang lebih efektif juga harus menjadi perhatian.

\section{Meningkatkan Mutu Sekolah}

Banyak pandangan ahli yang memberikan gambaran tentang upaya-upaya dalam menata ulang sekolah menjadi lebih berkualitas. Namun pendapat yang dikemukakan Stoll lebih dapat diterima. Stoll memberikan enam (enam) aspek penting yang harus menjadi perhatian untuk dapat meningkatkan mutu sekolah yaitu: 1) $A$ focus on process, 2) An orientation towards action and on-going development, 3) An emphasis on school-selected priorities for development, 4) An understanding of the importance of school culture, 5) The importance of a focus on teaching and learning, 6) A view of the school as the centre of change. Penulis mencoba menguraikan ke enam aspek tersebut dalam tulisan ini $^{14}$.

1) Fokus Pada proses

Perubahan di sekolah bukanlah suatu peristiwa atau usaha yang dapat diselesaikan dengan satu tindakan tertentu. Sebaliknya, ini merupakan proses yang membutuhkan waktu dan usaha yang nyata dan konsisten. Oleh karena itu seluruh komponen sekolah harus memilki fokus yang jelas dan fokus tersebut tentunya bermuara pada upaya penigkatan sekolah.

2) Orientasi terhadap tindakan dan pengembangan yang terus-menerus

Usaha perbaikan sekolah tidak cenderung menjadi solusi yang terkesan dipaksakan.Sebaliknya, perbaikan sekolah adalah upaya mewujudkan tujuan jangka panjang untuk mencapai visi sekolah. Selain itu dalam proses berjalannya, sekolah harus mampu memecahkan masalah-masalah yang terjadi. Sekolah tidak berdiri diam dan menunggu untuk diukur oleh orang lain. Sekolah merupakan lembaga yang dinamis, sering berubah. Hanya dengan mempelajari proses perubahan ini dan dampaknya harus benar-benar memahami kondisi sekolah.

\footnotetext{
${ }^{14}$ Stoll, L. (1994). School Effectiveness and School Improvement: A Meeting of Two Minds. Dalam David H. Hargreaves dan David Hopkins (Ed.). Development Planning For School improvement. Londaon \& Newyork :cassel (hal. 132-133)
} 


\section{3) Meprioritaskan Untuk Pembangunan}

Bebrbagai kajian tentang perbaikan sekolah selalu menekankan pada pentingnya melibatkan guru dalam upaya perubahan dan pada prioritas pengembangan sekolah. Hal ini sangat penting bahwa seluruh staff dapat dilibatkan dalam pemilihan prioritas sekolah untuk pengembangan di masa depan. Sekolah sengat penting untuk dapat menetapkan prioritas atau tujuan sekolah, karena hal ini nantinya menjadi pijakan yang melandasi setiap keputusan-keputusan sekolah selanjutnya.

4) Pemahaman Tentang Pentingnya Budaya Sekolah

Dalam beberapa tahun terakhir, kajian manajemen pendidikan tentang dampak kuat budaya organisasi dalam upaya perbaikan sekolah dan guru sangat banyak. Dan hal ini menjadikan pegangan bahwa budaya organisasi memilki andil besar dalam upaya perubahan sekolah. Sekolah yang sukses menyadari bahwa perencanaan pembangunan adalah tentang menciptakan budaya sekolah yang akan mendukung perencanaan dan manajemen perubahan berbagai aspek. Budaya sekolah sulit untuk didefinisikan, tetapi paling baik dipikirkan sebagai prosedur, nilai dan harapan yang memandu perilaku orang dalam suatu organisasi. Singkatnya, budaya yang mempromosikan kolaborasi, kepercayaan, pengambilan risiko, dan fokus pada pembelajaran berkelanjutan untuk siswa dan guru, adalah fitur utama untuk upaya perbaikan sekolah.

\section{5) Fokus Pada Prose Belajar Mengajar}

Seperti dijelaskan sebelumnya bahwa untuk dapat memperbaiki kualitas sekolah diperlukan fokus. Dalam hal ini perlu fokus terhadap pada guru dan proses pembelajaran di kelas. Guru memiliki tanggung jawab utama untuk menerapkan perubahan di sekolah yang dimulai pada pembelajaran di kelas. Guru memiliki peran yang paling atif dalam pelaksanaan pendidikan demi mencapai tujuan pendidikan yang hendak dicapai. Guru melaksanakan pendidikan melalui kegiatan pembelajaran dengan mengajar peserta didik atau siswa.

6) Melihat Sekolah Sebagai Pusat Perubahan

Peningkatan sekolah tidak hanya memandang sekolah sebagai fokus perubahan tetapi sebagai pusatnya. Kunci untuk peningkatan sekolah adalah memberikan dukungan yang tepat untuk sekolah dan juga terlibat dalam proses pembelajaran yang sedang berjalan. Sekolah harus menjadi bagian dari sistem yang lebih luas, jaringan 
dengan sekolah lain, komunitas, lembaga pendidikan tinggi dan dunia usaha dunia industri (DUDI).

Dengan demikian, proyek peningkatan sekolah yang komprehensif akan berfokus pada keenam aspek terssebut dengan menggabungkan berbagai kajian peningkatan sekolah; proses pengembangan sekolah dan strategi pengembangan; menekankan pentingnya budaya sekolah; kualitas dan kesetaraan kemajuan siswa, pengembangan dan pencapaian guru.

\section{KESIMPULAN}

Semua hal sangat dibutuhkan untuk dapat menigkatkan mutu sekolah bukan hanya kepemimpinan yang baik tetapi pendekatan holistik yang mempertahankan hubungan penting antara pengajaran dan pembelajaran yang sehat serta proses manajemen yang berkualitas.

Diharapkan pendidikan yang dikelola lembaga-lembaga Islam sudah harus diupayakan untuk mengalihkan paradigma yang berorientasikan ke masa lalu (abad pertengahan) ke paradigma yang berorientasi ke masa depan, yaitu mengalihkan dari paradigma pendidikan yang hanya mengawetkan kemajuan, ke paradigma pendidikan yang merintis kemajuan. Demi tegaknya peradaban Islam yang lebih kokoh. Jangan hanya mengingat kejayaan Islam masa lalu, karena mengingat kejayaan Islam masa lalu, sama saja seperti obat bius dalam dunia medis yang menghilangkan rasa sakit untuk sesaat, akan tetapi tidak menyembuhkan sakit itu sendiri.

Cara yang dapat ditempuh lembaga pendidikan islam dalam menata ulang lembaganya adalah dengan 1) fokus pada proses, 2) orientasi terhadap tindakan dan pengembangan yang terus-menerus, 3) meprioritaskan untuk pembangunan, 4) pemahaman tentang pentingnya budaya sekolah, 5) fokus pada prose belajar mengajar, 6) melihat sekolah sebagai pusat perubahan.

\section{DAFTAR PUSTAKA}

Hidayat, R. (2016). Ilmu Pendidikan Islam "Menuntun Arah Pendidikan Islam Indonesia. Medan: LPPPI

Hopkins, D., Stoll, L., Myers, K., Learmonth, J. And Durman, H. (1995). Schools Make A Difference: Practical Strategies For School Improvement, (Study 
Guide To Accompany The Channel 4 Series), Southampton, Resource Base Television Centre

Kurnaengsih. (2015). Konsep Sekolah Islam Terpadu (Kajian Pengembangan Lembaga Pendidikan Islam di Indonesia). Jurnal Risaalah. 1 (1). 78-84

Myers, K. (2005). School Improvement in Practice: Schools Make A Difference. London: Falmer Press

Sanaky, H. (2003). Paradigma Pendidikan Islam; Membangun Masyarakat Indonesia, Yogyakarta: Safiria Insania Press dan MSI.

Stoll, L. (1994). School Effectiveness and School Improvement: A Meeting of Two Minds. Dalam David H. Hargreaves dan David Hopkins (Ed.). Development Planning For School improvement. Londaon \& Newyork :cassel (hal. 129140)

Tan, C. (2011). Islamic Education and Indoctrination The Case in Indonesia. New York: Routledge

Yasmadi. (2005). Modernisasi Pesantren. Jakarta: Ciputat Press.

Yusuf, C. dan Suwito, NS (2009). Model Pengembangan Ekonomi Pesantren. Purwokerto: STAIN Press. 